\title{
Tetrathiafulvalene-based azine ligands for anion and metal cation coordination
}

\author{
Awatef Ayadi ${ }^{1,2}$, Aziz El Alamy ${ }^{3}$, Olivier Alévêque ${ }^{1}$, Magali Allain ${ }^{1}$, Nabil Zouari ${ }^{2}$, \\ Mohammed Bouachrine ${ }^{3}$ and Abdelkrim El-Ghayoury ${ }^{* 1}$
}

Open Access

\author{
Full Research Paper \\ Address: \\ ${ }^{1}$ Laboratoire MOLTECH Anjou, Université d'Angers, UFR Sciences, \\ UMR 6200, CNRS, Bât. K, 2 Bd. Lavoisier, 49045 Angers Cedex, \\ France, ${ }^{2}$ Laboratoire de Physico-chimie de l'état solide, Université de \\ Sfax, Route de Soukra; Km 4; BP: 802, 3038, Sfax, Tunisia and \\ ${ }^{3}$ MEM, High School of Technology (ESTM), University, Moulay Ismail, \\ Meknès, Morocco \\ Email: \\ Abdelkrim El-Ghayoury - abdelkrim.elghayoury@univ-angers.fr \\ * Corresponding author \\ Keywords: \\ azine ligand; fluoride sensing; rhenium; tetrathiafulvalene; X-ray
}

Beilstein J. Org. Chem. 2015, 11, 1379-1391. doi:10.3762/bjoc. 11.149

Received: 24 March 2015

Accepted: 12 July 2015

Published: 07 August 2015

This article is part of the Thematic Series "Tetrathiafulvalene chemistry".

Guest Editor: P. J. Skabara

(C) 2015 Ayadi et al; licensee Beilstein-Institut. License and terms: see end of document.

\begin{abstract}
The synthesis and full characterization of two tetrathiafulvalene-appended azine ligands, namely 2-([2,2'-bi(1,3-dithiolylidene)]-4yl)-6-((2,4-dinitrophenyl)hydrazono)methyl)pyridine (L1) and 5-([2,2'-bi(1,3-dithiolylidene)]-4-yl)-2-((2,4-dinitrophenyl)hydrazono)methyl)pyridine (L2) are described. The crystal structure of ligand $\mathbf{L 1}$ indicates that the ligand is completely planar with the

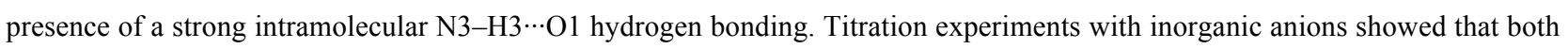
ligands are suitable candidates for the sensing of fluoride anions. Ligand $\mathbf{L} \mathbf{2}$ was reacted with a $\operatorname{Re}(\mathrm{I})$ cation to yield the corresponding rhenium tricarbonyl complex 3. In the crystal structure of the newly prepared electroactive rhenium complex the TTF is neutral and the rhenium cation is hexacoordinated. The electrochemical behavior of the three compounds indicates that they are promising for the construction of crystalline radical cation salts.
\end{abstract}

\section{Introduction}

Tetrathiafulvalene (TTF) is known to have excellent electrondonating properties resulting in stable radical cation $\left(\mathrm{TTF}^{\bullet+}\right)$ and dication $\left(\mathrm{TTF}^{2+}\right)$ species from two sequential and reversible oxidation processes. The huge interest in the synthesis of TTF and its very numerous derivatives [1] has been initiated by the high electrical conductivity discovered in a chloride salt of TTF [2] and metallic behavior in the charge-transfer complex with 7,7,8,8-tetracyano-p-quinodimethane (TCNQ) [3]. These systems have played a major role for the preparation of molecular materials designed for various applications. They have been, for example, used as electron donor molecules to prepare electrically (super)conducting crystalline materials [4-7], as solar energy systems [8,9] or even as donor moieties in nonlinear optical (NLO) materials $[10,11]$. In the last decades one of the biggest challenges in materials science is devoted to the preparation of multifunctional molecular materials that can 
potentially exhibit, in solution and/or in solid state, synergy or coexistence between two or more different physical properties. In order to address this issue, many efforts have been devoted to the association of a binding or coordinating unit to the redoxactive TTF moiety. This strategy has led for example, in solid state, to the preparation of electroactive metal complexes that combine magnetic and electrical properties [12-17]. In solution, TTF-based redox-responsive receptors for neutral and/or charged guest sensing applications have been prepared [18-22]. On this ground, chemosensors capable of recognizing anionic and/or cationic species constitute an important area of increasing research in supramolecular chemistry, considering the ubiquitous properties of both anions and metal cations [2327]. In fact, anions are involved in a large number of biological and chemical processes [28-31]. Note that fluoride is of particular interest among the other inorganic anions because of its both beneficial (e.g., preventing dental caries and treatment of osteoporosis) and detrimental (e.g., fluorisis) effects on human health [32-34]. Many TTF derivatives have been used to coordinate or to bind separately metal cations [35] or inorganic anions [36], however only few examples were used for both inorganic anions and metal cations coordination [37].

Herein we report the synthesis and electronic properties of two new multifunctional TTF-based azine ligands that integrate distinctive functional groups as depicted in Scheme 1 and thus capable of coordinating both metal cations as well as inorganic anions. The sensing studies for inorganic anions are discussed. Metal cation complexation studies of the new ligands afforded the formation and the structural characterization of a neutral rhenium complex.

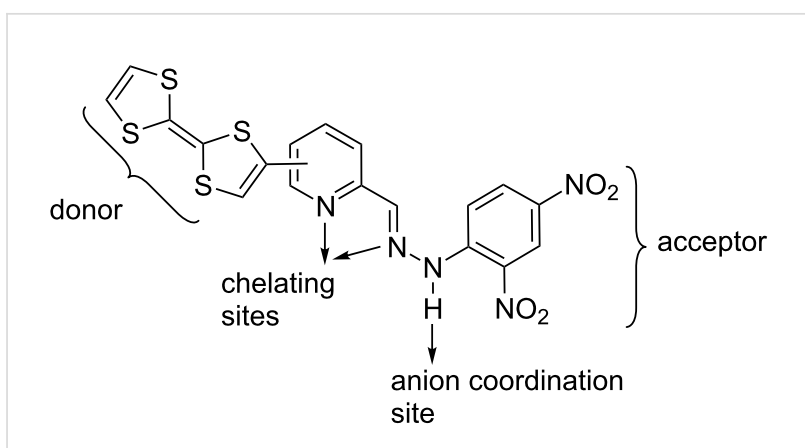

Scheme 1: Multifunctional TTF-appended azine ligands.

\section{Results and Discussion}

\section{Synthesis of the ligands $\mathbf{L} 1$ and $\mathbf{L} 2$}

The protocol followed for the synthesis of the new azine ligands $\mathbf{L 1}$ and $\mathbf{L 2}$ is summarized in Scheme 2. The reaction of 6-bromo-2-pyridinecarboxaldehyde or 5-bromo-2-pyridinecarbox-

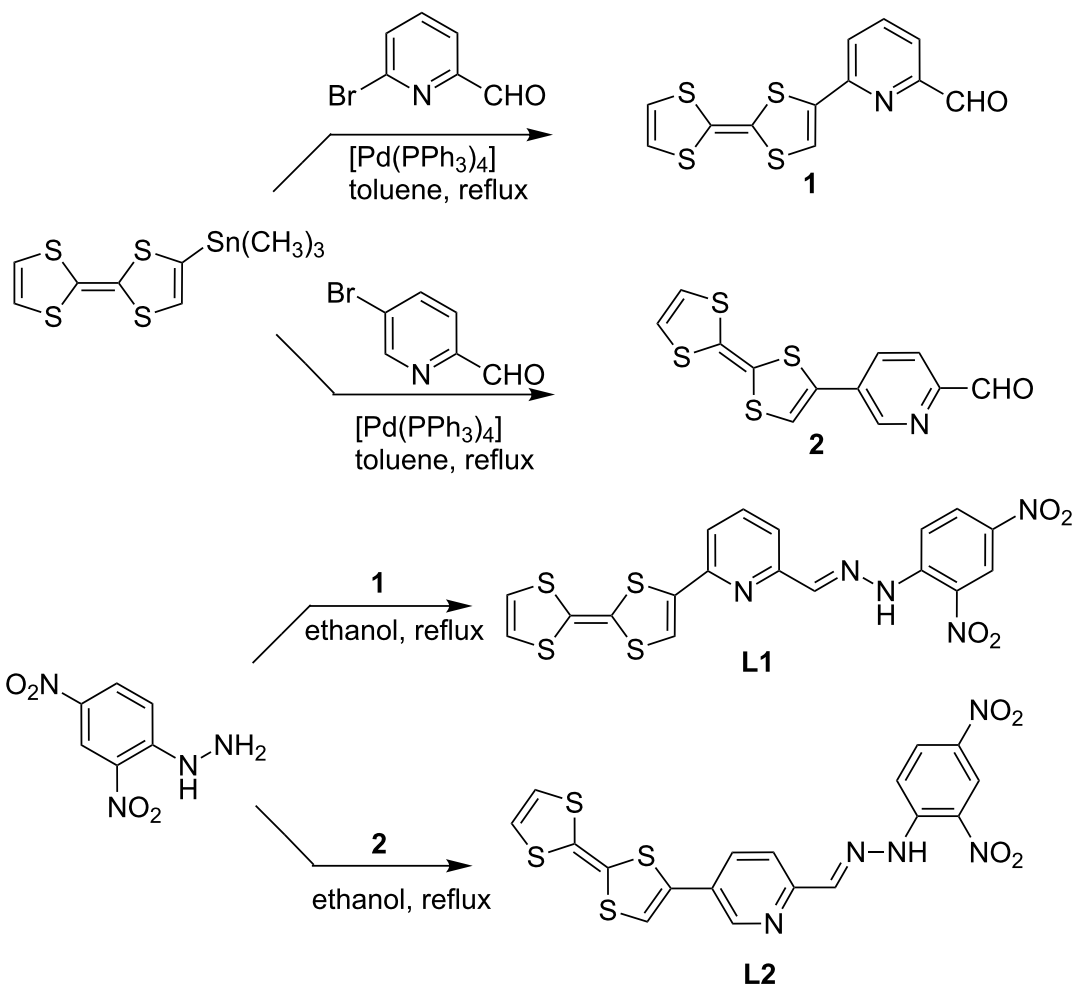

Scheme 2: Synthetic scheme for TTF-based azine ligands L1 and L2. 
aldehyde with one equivalent of TTF-SnMe 3 under the Stille coupling conditions, using $\left[\mathrm{Pd}\left(\mathrm{PPh}_{3}\right)_{4}\right]$ as catalyst in toluene, afforded the intermediates 6-([2,2'-bi(1,3-dithiolylidene)]-4yl)picolinaldehyde (1, previously described in reference [38]) and 5-([2,2'-bi(1,3-dithiolylidene)]-4-yl)picolinaldehyde (2) in good yields (60\% and 65\%, respectively), after chromatographic work-up. Condensation of pyridinealdehyde-functionalized TTF 1 or 2 with 2,4-dinitrophenylhydrazine, in refluxing ethanol, afforded the desired ligands $\mathbf{L} 1$ and $\mathbf{L 2}$ in $75 \%$ and $63 \%$ isolated yields, respectively. The structures of the new ligands were characterized by ${ }^{1} \mathrm{H}$ and ${ }^{13} \mathrm{C}$ NMR, UV-visible and IR spectroscopy, high resolution mass spectrometry and elemental analysis.

\section{Crystal structure description}

Details about data collection and structure refinement are given in Table 1. Crystallographic data for the structural analysis have been deposited within the Cambridge Crystallographic Data Centre, CCDC 1055120 (ligand L1) and CCDC 1055119 (complex 3).

Suitable single crystals for X-ray analysis have been grown for ligand $\mathbf{L 1}$ upon recrystallization from DMSO solution. Ligand $\mathbf{L} 1$ crystallizes as dark plates in the orthorhombic system, space group Pbca and selected bond lengths and angles are depicted in Table 2. As it can be seen in Figure 1, ligand $\mathbf{L 1}$ is completely planar. The dihedral angle between the dinitrophenylhydrazone and pyridine planes is $2.67(2)^{\circ}$ which is slightly lower than the dihedral angle observed in the case of the pyridine-2-carbaldehyde 2,4-dinitrophenylhydrazone that is $3.88(8)^{\circ}$ [39]. The molecular conformation of the ligand is stabilized by a strong

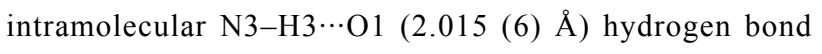
making the dinitrophenyl ring coplanar with the hydrazone

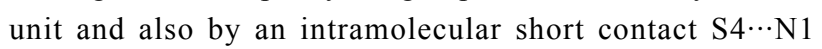

\begin{tabular}{|c|c|c|}
\hline compound & Ligand L1 & Complex 3 \\
\hline Empirical formula & $\mathrm{C}_{78} \mathrm{H}_{62} \mathrm{~N}_{20} \mathrm{O}_{19} \mathrm{~S}_{19}$ & $\mathrm{C}_{42} \mathrm{H}_{24} \mathrm{Cl}_{2} \mathrm{~N}_{10} \mathrm{O}_{15} \mathrm{Re}_{2} \mathrm{~S}_{8}$ \\
\hline fw & 2192.62 & 1608.49 \\
\hline$T(\mathrm{~K})$ & $293(2)$ & $180.0(1)$ \\
\hline cryst syst & Orthorhombic & Triclinic \\
\hline space group & Pbca & $P 1$ \\
\hline$a(\AA)$ & $7.353(3)$ & $8.591(1)$ \\
\hline$b(\AA)$ & $30.35(1)$ & $11.501(1)$ \\
\hline$c(\AA)$ & $20.894(6)$ & $15.567(2)$ \\
\hline$V\left(\AA^{3}\right)$ & $4663(3)$ & $1478.3(3)$ \\
\hline$Z$ & 2 & 1 \\
\hline$D_{\mathrm{c}}\left(\mathrm{g} \mathrm{cm}^{-3}\right)$ & 1.562 & 1.807 \\
\hline abs coeff $\left(\mathrm{mm}^{-1}\right)$ & 0.517 & 11.955 \\
\hline$F(000)$ & 2252 & 778 \\
\hline cryst size $\left(\mathrm{mm}^{3}\right)$ & $0.26 \times 0.04 \times 0.02$ & $0.2061 \times 0.0406 \times 0.0194$ \\
\hline$\theta$ range for data collection (deg) & $3.01-24.98$ & $2.94-72.85$ \\
\hline $\operatorname{Tmin} / \operatorname{Tmax}$ & $0.867 / 0.990$ & $0.656 / 1.000$ \\
\hline reflns collected & 32107 & 8638 \\
\hline GOF on $F^{2}$ & 1.093 & 1.041 \\
\hline final $R$ indices $[I>2 \sigma(I)]$ & $\mathrm{R} 1=0.0947, w R 2=0.1705$ & $\mathrm{R} 1=0.0987, w R 2=0.2569$ \\
\hline$R$ indices (all data) & $\mathrm{R} 1=0.2089, \mathrm{wR} 2=0.2046$ & $\mathrm{R} 1=0.1458, w R 2=0.2810$ \\
\hline largest diff. peak and hole $\left(e \AA^{-3}\right)$ & 0.255 and -0.310 & 2.290 and -2.053 \\
\hline X-ray wavelength radiation & Mo $\mathrm{K}_{\mathrm{a}}$ & $\mathrm{Cu} \mathrm{K}_{\alpha}$ \\
\hline
\end{tabular}




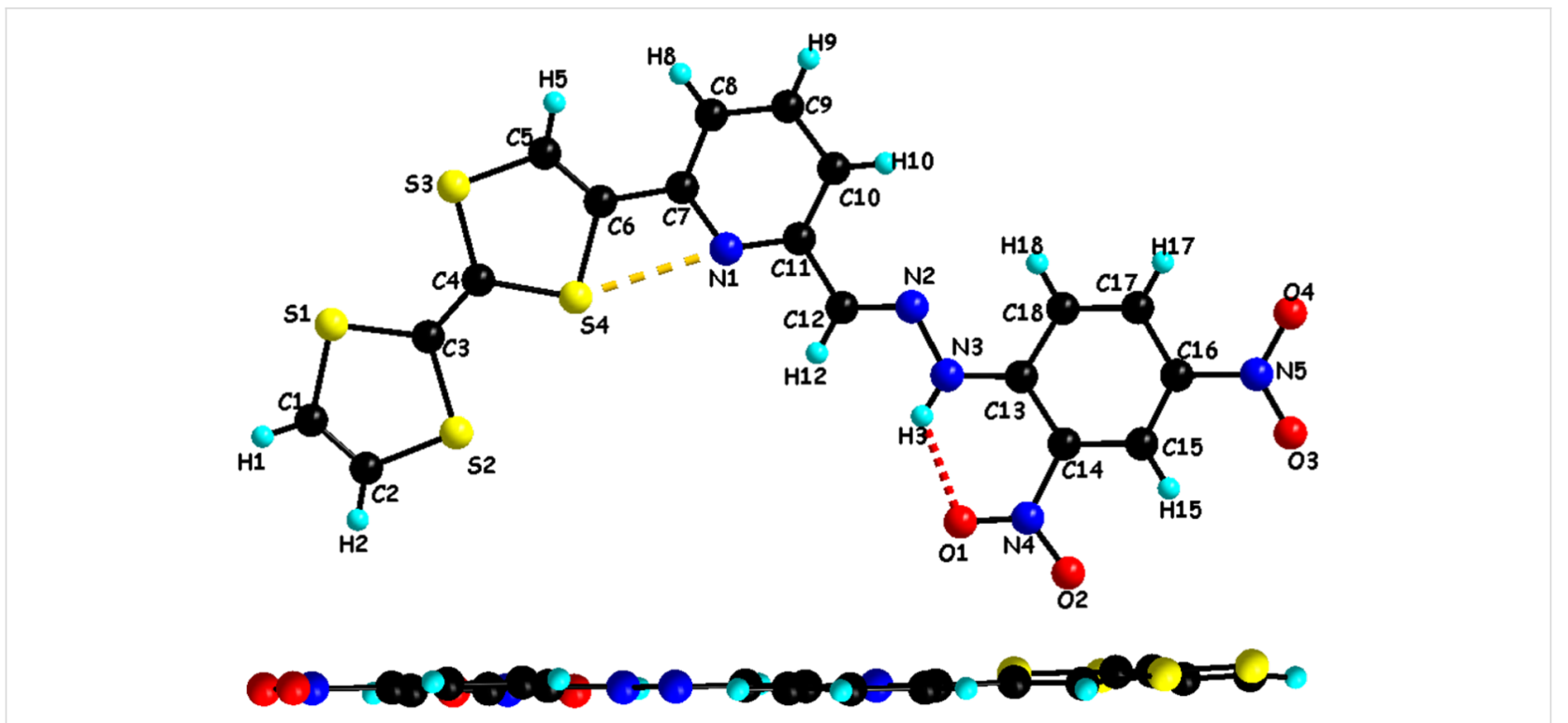

Figure 1: Crystal structure of ligand L1 with atom numbering scheme (top) and a side view of the molecule (bottom).

Table 2: Selected bond lengths $(\AA)$ and angles $\left({ }^{\circ}\right)$ in L1.

Bond length $(\AA)$

\begin{tabular}{llll}
\hline C1-S1 & $1.749(8)$ & C6-C7 & $1.487(9)$ \\
C1-C2 & $1.310(9)$ & C7-N1 & $1.361(8)$ \\
C2-S2 & $1.745(7)$ & N1-C11 & $1.324(8)$ \\
C3-S2 & $1.789(7)$ & C11-C12 & $1.463(9)$ \\
C3-S1 & $1.748(8)$ & C12-N2 & $1.256(8)$ \\
C3-C4 & $1.349(9)$ & N2-N3 & $1.383(7)$ \\
C4-S3 & $1.741(7)$ & N3-C13 & $1.340(8)$ \\
C4-S4 & $1.779(7)$ & C13-C14 & $1.431(9)$ \\
S4-C6 & $1.777(6)$ & C14-N4 & $1.474(9)$ \\
C6-C5 & $1.337(8)$ & N4-O1 & $1.217(8)$
\end{tabular}

Angle values $\left({ }^{\circ}\right)$

\begin{tabular}{llll}
\hline N1-C11-C10 & $123.7(7)$ & N2-N3-C13 & $119.0(6)$ \\
C12-N2-N3 & $117.2(6)$ & C18-C13-N3 & $120.3(6)$ \\
C11-C12-N2 & $121.9(7)$ & C13-C14-N4 & $120.9(7)$
\end{tabular}

(2.824(6) $\AA$ ) that makes the TTF unit and the pyridine ring coplanar.

In the solid state, the packing arrangement in $\mathbf{L} \mathbf{1}$ is characterized by the self-assembly between the TTF donor unit and the dinitrophenyl acceptor unit forming head-to-tail dimers. Moreover, the plane-to-plane distance between the donor and acceptor moieties is $d=3.39 \AA$, showing an evident overlap that is comparable to the reported intermolecular charge-transfer complexes [35]. This overlap develops along $a$-axis forming infinite columns (Figure 2). These columns are linked together along $c$-axis through hydrogen bonding occurring between TTF-C-H and $\mathrm{NO}_{2}$ (TTF-C-H1 $\left.\cdots \mathrm{O} 3-\mathrm{NO} 2.493(6) \AA\right)$.

In the $b$-direction, the columns of stacked head to tail molecules are connected laterally through $\mathrm{S} \cdots \mathrm{O}$ heteroatom contacts ( $d=3.16 \AA$, Figure S1, Supporting Information File 1) resulting in alternating stacks with a "zig zag" like manner with an angle of rotation of $135.6^{\circ}$ (Figure 3 ).

\section{UV-visible absorption spectroscopy}

The UV-visible absorption spectra of the ligands L1 and L2 were recorded in a mixture of dichloromethane/acetonitrile solution $\left(9 / 1, \mathrm{v} / \mathrm{v}, \mathrm{C}=2 \times 10^{-5} \mathrm{M}\right)$ at room temperature (Figure 4). The two ligands exhibit strong electronic absorption bands between $\lambda=300 \mathrm{~nm}$ and $450 \mathrm{~nm}$ which are assigned to the $\pi \rightarrow \pi^{*}$ and $n \rightarrow \pi^{*}$ absorption bands resulting from the different units of the two ligands (TTF moiety, pyridyl ring and the dinitrophenylhydrazone group). As compared to ligand $\mathbf{L} 1$, $\mathbf{L 2}$ exhibits an additional absorption band around $\lambda=516 \mathrm{~nm}$ which is attributed to an intramolecular charge transfer (ICT) excitation from the TTF donor moiety to the dinitrophenylhydrazone accepting group. These results from a strong $\pi$-electronic delocalization that occurs in ligand $\mathbf{L 2}$ leading to a resonance structure that involves the $\mathrm{C}=\mathrm{N}$ hydrazone bond as it can be seen in (Figure S2, Supporting Information File 1).

\section{Theoretical calculations}

Theoretical calculations based on density functional theory (DFT) methods have been performed with the Gaussian 09 program [40]. Becke's three-parameter gradient-corrected functional (B3LYP) with 6-31G (d) basis in vacuum was used for 


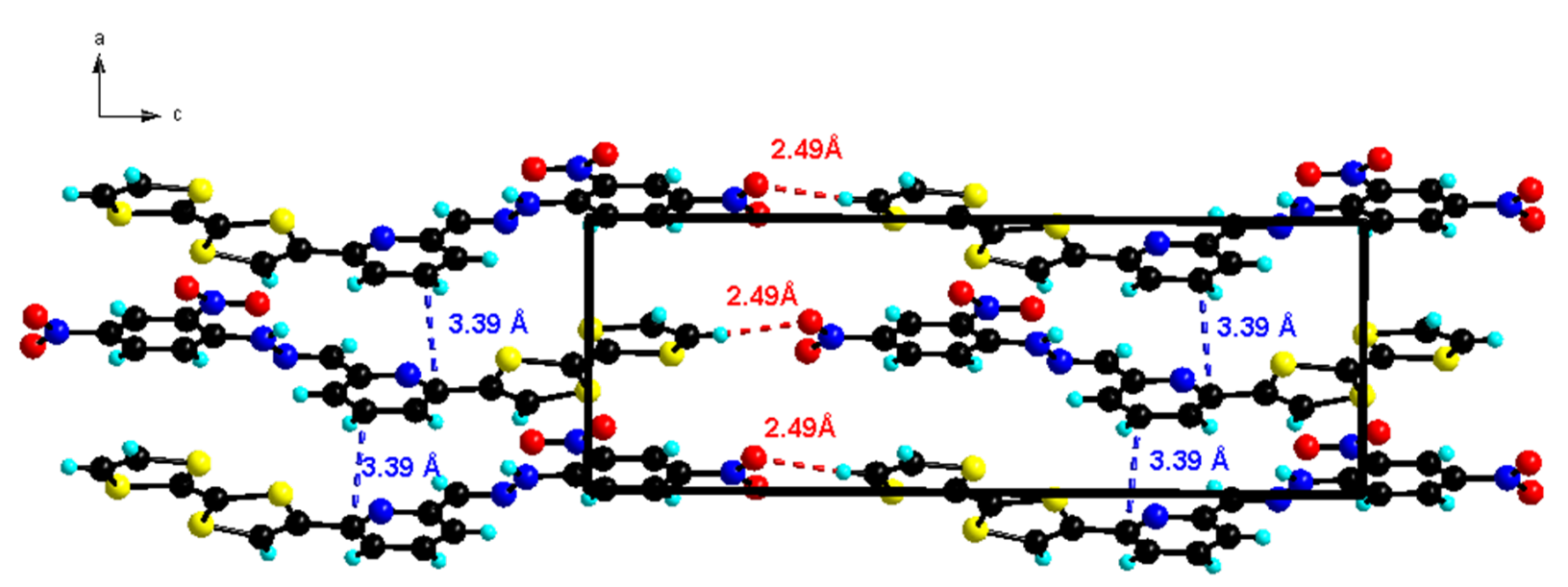

Figure 2: Partial crystal packing of ligand $\mathbf{L} 1$ with formation of head to tail dimers that stack along a-axis forming columns that are connected through hydrogen bonding along $c$-axis.

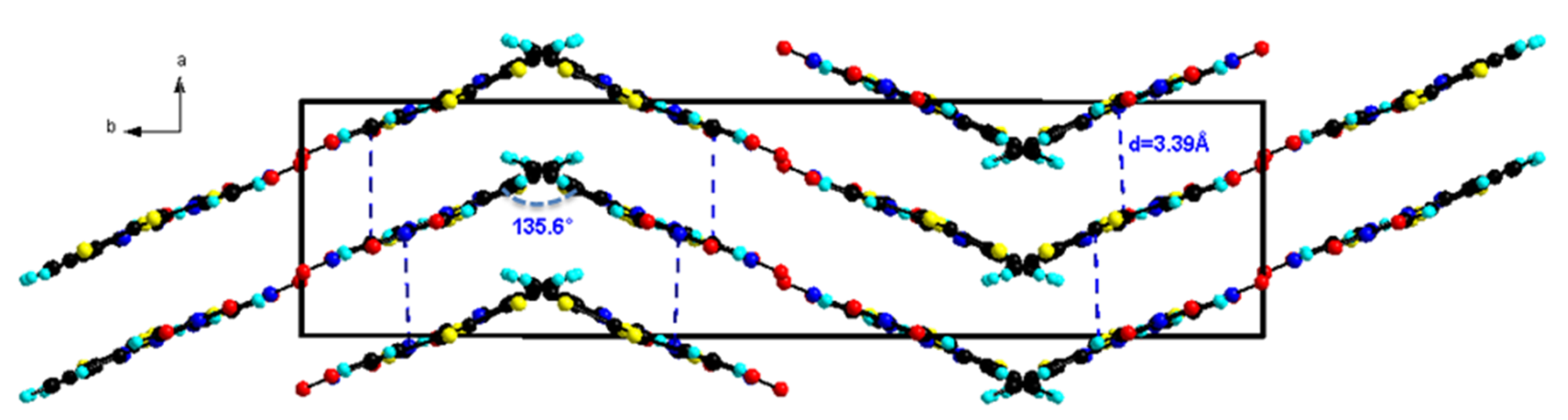

Figure 3: Packing diagram of L1 showing the orientation of the columns of head to tail dimers

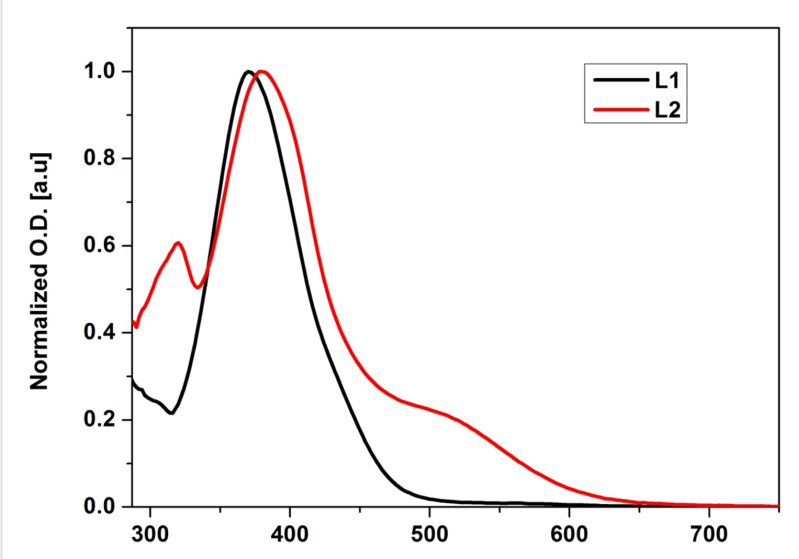

Figure 4: UV-visible absorption spectra of ligands L1 and L2 $\left(c 2.5 \times 10^{-5} \mathrm{M}\right.$ in (dichloromethane/acetonitrile, 9:1, v/v)), room temperature.

full geometry optimization of the two ligands. The resulting frontier molecular orbitals (Figure 5) for ligands L1 and L2 indicate that the electron density of the highest occupied molec- ular (HOMO) orbitals develop exclusively on the TTF fragment. The LUMO orbital for ligand $\mathbf{L} 1$ is essentially distributed on the nitrophenylhydrazino group with a small participation of the pyridyl ring, while for ligand $\mathbf{L} 2$ it is distributed on the $\pi$-extended system with a small participation of the external ethylenic atom of the TTF moiety which is confirming the good electronic conjugation in this ligand. The same behavior is observed for the TTF pyridine carboxaldehyde precursors 1 and 2 (Figure S3, Supporting Information File 1).

\section{Cyclic voltammetry}

The electrochemical behavior of the electroactive precursors 1 and $\mathbf{2}$ as well as of ligands $\mathbf{L} \mathbf{1}$ and $\mathbf{L} \mathbf{2}$ was investigated by cyclic voltammetry (Figure 6 and Table 3). The measurements in the case of precursors $\mathbf{1}$ and $\mathbf{2}$ show two reversible oxidations at $E_{1 \mathrm{ox}}=+0.26 \mathrm{~V}, E_{2 \mathrm{ox}}=+0.75 \mathrm{~V}$ and $E_{1 \mathrm{ox}}=+0.32 \mathrm{~V}$, $E_{2 \mathrm{ox}}=+0.77 \mathrm{~V}$ vs $\mathrm{Ag} / \mathrm{Ag}^{+}$, respectively, that are anodically shifted when compared to the ones of the free TTF because of the presence of the electron deficient pyridinecarboxaldehyde moiety. In addition, $E_{1 \text { ox }}$ of $\mathbf{2}$ is anodically shifted when 


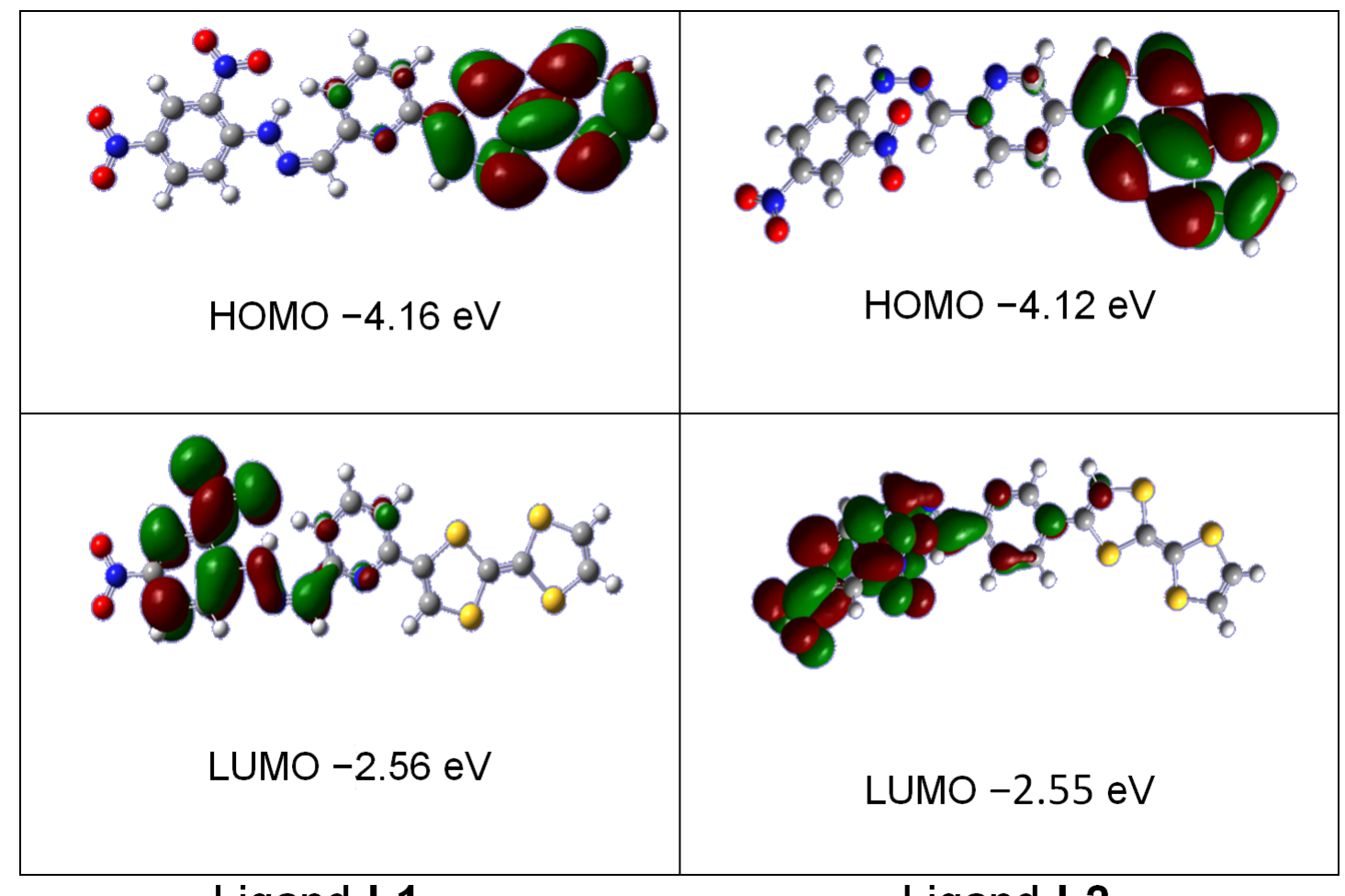

Ligand L1

Ligand L2

Figure 5: HOMO-LUMO Frontier orbitals representation for ligands L1 and L2.

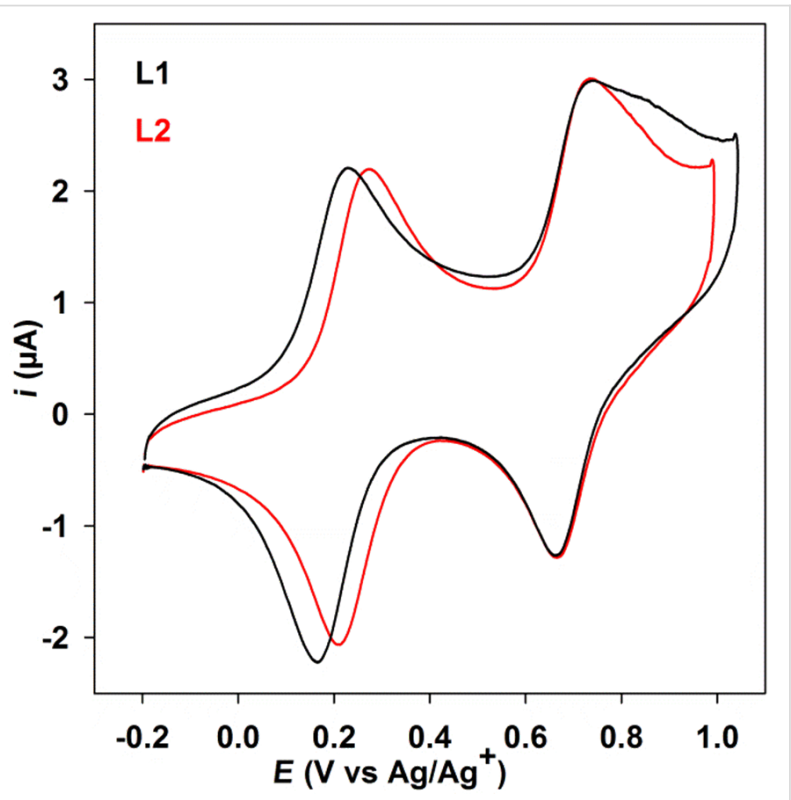

Figure 6: Cyclic voltammograms of ligands $\mathbf{L} 1$ and $\mathbf{L} 2\left(2 \times 10^{-5} \mathrm{M}\right)$ in $\mathrm{CH}_{2} \mathrm{Cl}_{2} / \mathrm{CH}_{3} \mathrm{CN}(9: 1, \mathrm{v} / \mathrm{v})$ at $100 \mathrm{mV} \cdot \mathrm{s}^{-1}$ on a glassy carbon electrode with $n-\mathrm{Bu}_{4} \mathrm{NPF}_{6}(0.1 \mathrm{M})$.

compared with $E_{1 \text { ox }}$ of $\mathbf{1}$, indicating a strong $\pi$-electron conjugation in precursor $\mathbf{2}$. As for $\mathbf{1}$ and 2, ligands $\mathbf{L} \mathbf{1}$ and $\mathbf{L} \mathbf{2}$ show two reversible oxidations at $E_{1 \mathrm{ox}}=+0.20 \mathrm{~V}, E_{2 \mathrm{ox}}=+0.70 \mathrm{~V}$
Table 3: Apparent redox potentials $(\mathrm{V})$ of molecular compounds 1, 2, L1 and L2 reported vs $\mathrm{Ag} / \mathrm{Ag}^{+}(0.01 \mathrm{M})$ in $0.1 \mathrm{M} \mathrm{TBAPF}$ in $\mathrm{CH}_{2} \mathrm{Cl}_{2}$ / $\mathrm{CH}_{3} \mathrm{CN} 3: 1$ on glassy carbon electrode at $100 \mathrm{mV} \cdot \mathrm{s}^{-1}$.

\begin{tabular}{ccc} 
compound & $E_{\mathrm{ox} 1}$ & $E_{\mathrm{ox} 2}$ \\
\hline $\mathbf{1}$ & 0.26 & 0.75 \\
$\mathbf{2}$ & 0.32 & 0.77 \\
L1 & 0.20 & 0.70 \\
L2 & 0.25 & 0.70
\end{tabular}

and $E_{1 \mathrm{ox}}=+0.25 \mathrm{~V}, E_{2 \mathrm{ox}}=+0.70 \mathrm{~V}$ vs $\mathrm{Ag} / \mathrm{Ag}^{+}$, respectively) that are cathodically shifted when compared to the ones of 1 and $\mathbf{2}$ indicating that the pyridine-hydrazone group is less electron deficient than the corresponding pyridinecarboxaldehyde. In addition, $E_{1 \text { ox }}$ of $\mathbf{L 2}$ is also anodically shifted when compared with $E_{1 \text { ox }}$ of $\mathbf{L} \mathbf{1}$ because of the strong $\pi$-electron conjugation in ligand $\mathbf{L} \mathbf{2}$ and this is in agreement with the bathochromic shift observed for $\mathbf{L} \mathbf{2}$ in the UV-visible absorption spectra.

\section{Sensing properties of the azine ligands for anions}

It is known that phenylhydrazone groups are able to act as optical sensors particularly for fluoride anions [41-45]. Thus, the colorimetric sensing abilities of the two ligands $\mathbf{L 1}$ and $\mathbf{L 2}$ 
were investigated by adding various anions such as hydrogensulfate, acetate, iodine and fluoride (used as tetrabutylammonium salts) in a mixture of dichloromethane/acetonitrile (9:1, $\mathrm{v} / \mathrm{v})$. Addition of increasing amounts of $\mathrm{F}^{-}$causes a dramatic change in color from yellow to violet that can be observed by the naked eye (Figure S4 in Supporting Information File 1), which is accompanied by the formation of a new broad absorption band centered at about $510 \mathrm{~nm}$ in the case of ligand L1. In the case of ligand $\mathbf{L 2}$, addition of $\mathrm{F}^{-}$(Figure 7) causes also a dramatic change in color from light orange to violet that can be observed by the naked eye (Figure S5 in Supporting Information File 1), that is accompanied by a decrease of the intense absorption band centered at about $380 \mathrm{~nm}$ and the increase of the ICT absorption band centered around $540 \mathrm{~nm}$. This change is likely due to the deprotonation of the hydrazone nitrogen which causes an enhancement of charge transfer from the TTF unit and the deprotonated nitrogen to the electron poor 2,4-dinitrophenyl moiety [36]. A remarkable feature is the occurrence of a quite well defined isosbestic point at $420 \mathrm{~nm}$ and $447 \mathrm{~nm}$ for $\mathbf{L 1}$ and $\mathbf{L 2}$, respectively, indicating that $\mathbf{L 1}$ or $\mathbf{L 2}$ coexist with only one species upon addition of TBAF. Note that upon addition of other inorganic anions such as bromide, chloride or hydrogensulfate we have observed a negligible absorption changes while in the case of acetate anion a moderate absorption changes are obtained (Figures S6 and S7 in Supporting Information File 1) [46].

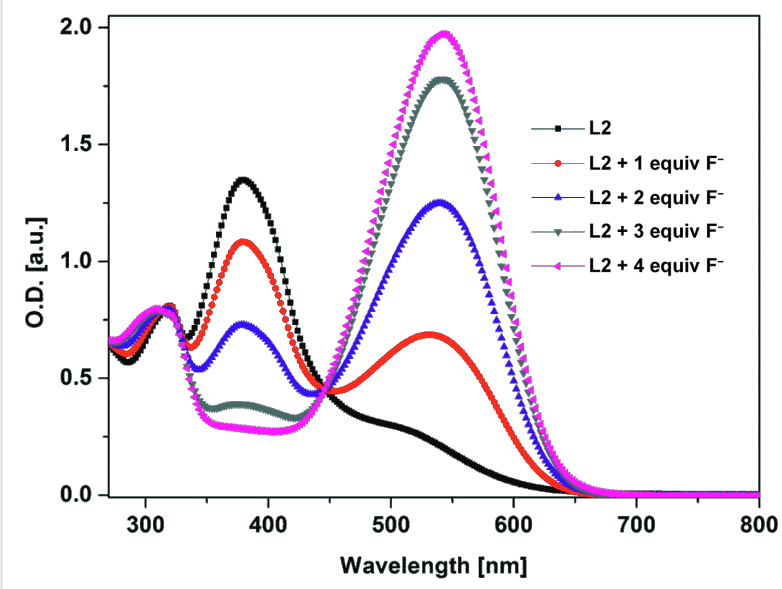

Figure 7: UV-visible spectral changes of ligand $L 2\left(2 \times 10^{-5} \mathrm{M}\right.$ in $\left.\mathrm{CH}_{2} \mathrm{Cl}_{2} / \mathrm{CH}_{3} \mathrm{CN}, 9 / 1\right)$ upon addition of TBAF.

Treatment of an electrolytic solution of ligand $\mathbf{L 1}$ or $\mathbf{L 2}$ with an increasing amount of fluoride anion (tetrabutylammonium fluoride trihydrate in a $\mathrm{CH}_{2} \mathrm{Cl}_{2} / \mathrm{CH}_{3} \mathrm{CN}$ mixture) involve the presence, as previously seen for fluoride anion sensing [47], and mainly on the first cycle, of the pre-wave superimposed on the wave of oxidation of the ligands. We clearly see on the second cycle a negligible change of the oxidation potential of the ligand which is very likely because of the large distance between the TTF and the fluoride coordinating unit (Figure S8 in Supporting Information File 1).

In order to get further supports to the observed optical sensing and to get deeper insights into the interactions between $\mathbf{L 1}$ or L2 and fluoride, ${ }^{1} \mathrm{H}$ NMR titration experiments were performed in DMSO- $d_{6}$ (Figure 8 and Figure S9 in Supporting Information File 1). The measurements indicate that the $\mathrm{N}-\mathrm{H}$ peak disappears after addition of one equivalent of TBAF while the other aromatic proton resonances of $\mathbf{L} 1$ or $\mathbf{L} 2$ exhibit an upfield shift. These results tend to be consistent with the deprotonation of the $\mathrm{N}-\mathrm{H}$ group and the delocalization of the negative charge over the $\pi$-conjugated system as previously observed TTF dinitrophenylhydrazone [36]. Note that there is no change in the ${ }^{1} \mathrm{H}$ NMR spectrum observed for other anions.

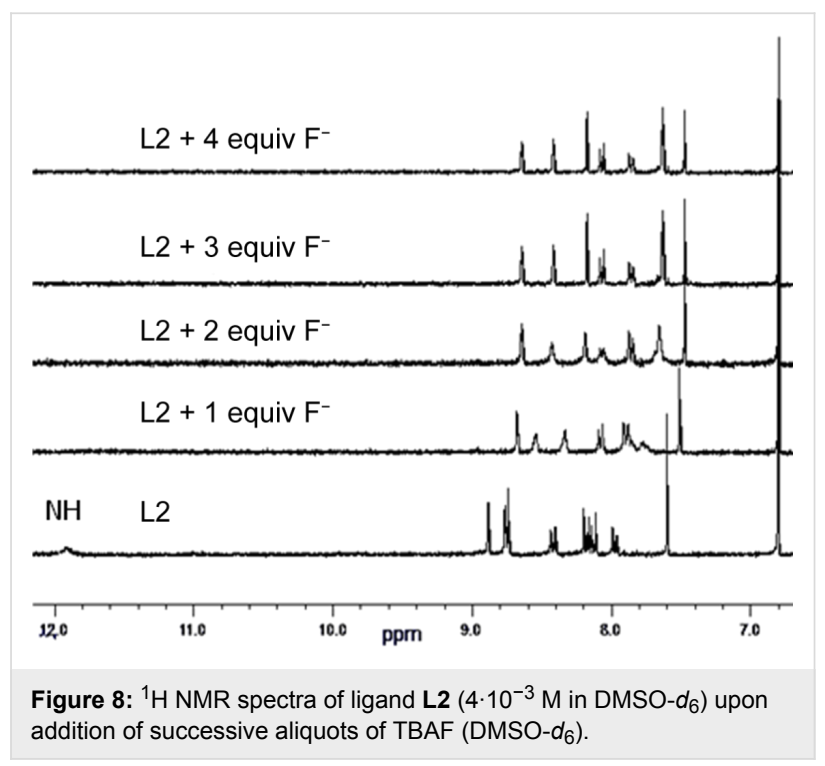

\section{Synthesis and crystal structure of a neutral rhenium complex}

Few metal complexes based on ruthenium cations have been previously prepared with dinitrophenylazine type ligands $[48,49]$. These reports indicate that the pyridinedinitrophenylazine type ligands are good candidates for the formation of metal complexes. We have therefore investigated the complexation of $\mathbf{L 1}$ and $\mathbf{L} 2$ with various metal cations and we succeeded in the crystallization of a neutral rhenium metal complex with ligand $\mathbf{L 2}$. Thus, the equimolar reaction between $\mathbf{L} 2$ and the $\left[\mathrm{Re}(\mathrm{CO})_{5} \mathrm{Cl}\right]$ precursor performed in refluxing toluene, under no light and inert atmosphere, afforded a mononuclear neutral complex 3 described as $\left[\operatorname{Re} \mathbf{L} 2(\mathrm{CO})_{3} \mathrm{Cl}\right] \cdot 0.5 \mathrm{H}_{2} \mathrm{O}$ as a dark precipitate [50]. Single crystals of $\mathbf{3}$ were obtained by recrystallization from acetone/hexane solution. Details about data collection and structure refinement are given in Table 1. As expected, 
the resulting metal complex 3 is composed of one ligand $\mathbf{L} 2$ coordinated to $\mathrm{Re}(\mathrm{CO})_{3} \mathrm{Cl}$ fragment through two nitrogen atoms of the pyridine and the $\mathrm{C}=\mathrm{N}$ hydrazone group (Figure 9). Upon complexation, the ligand acquires a cis-conformation of the hydrazinopyridine moiety in contrast to the trans-conformation observed for free ligand L1 (see Figure 1 and Figure 9). Within the complex, the rhenium center is surrounded by the bidentate chelating L2 ligand, three carbonyl ligands arranged in a facial fashion, and a chlorine atom and its coordination sphere presents the expected, although slightly distorted, octahedral geometry. The angle formed by the rhenium center and $\mathrm{N}$ atoms equals to $73.6(5)^{\circ}$ which is smaller than the angle of $90^{\circ}$ adopted in an ideal octahedron. In addition, in the complex the $\mathrm{C}-\mathrm{Re}-\mathrm{C}$ angles identified as C19-Re1-C20, C19-Re-C21, $\mathrm{C} 20-\mathrm{Re}-\mathrm{C} 21$ are $87.7^{\circ}, 91.7^{\circ}$ and $90.9^{\circ}$, respectively, which are close to $90^{\circ}$ indicating that $\mathrm{CO}$ ligands are almost linearly coordinated to the rhenium(I) cation. The length of the two Re-N bonds are (N1-Re1 2.20(1) A) and N2-Re1 2.18(1) $\AA$, and the formal double bond character $\mathrm{C}=\mathrm{N}$ is maintained (C12-N2 1.32(2) $\AA$ ). All three Re-CO bond lengths are very close, and the $\mathrm{Re}-\mathrm{C}-\mathrm{O}$ angles present minor deviations from linear structure, values ranging from $165(2)^{\circ}$ to $177(2)^{\circ}$ (Table 4).

In the crystal structure, the chlorine atom coordinated to rhenium is involved in an intramolecular $\mathrm{C}-\mathrm{H} \cdots \mathrm{Cl}$ hydrogen bonding with the hydrogen from the pyridyl ring with a distance of 2.581(6) $\AA$. In addition, it is involved in an intermolecular hydrogen bonding with a neighboring molecule by a strong TTF-C- $\mathrm{H} \cdots \mathrm{Cl}$ bond (2.659(6) $\AA$ ) resulting in the formation of dimers that are formed with a $\mathrm{R}_{2}^{2}(16)$ cyclic motif (grey filling in Figure 10) as it was previously observed within a catecholappended TTF derivative [51].

Table 4: Selected bond lengths $(\AA)$ and angles $\left({ }^{\circ}\right)$ in complex 3 .

Bond length $(\AA)$

\begin{tabular}{llll}
\hline N1-Re1 & $2.20(1)$ & C20-Re1 & $1.96(2)$ \\
N2-Re1 & $2.18(1)$ & C19-Re1 & $1.89(2)$ \\
Cl1-Re1 & $2.39(8)$ & C11-N1 & $1.35(2)$ \\
C21-Re1 & $2.19(1)$ & C11-C12 & $1.43(2)$
\end{tabular}

Angle values $\left({ }^{\circ}\right)$

\begin{tabular}{llll}
\hline C19-Re1-C20 & $87.7(9)$ & N2-Re1-N1 & $73.6(5)$ \\
C19-Re1-C21 & $91.7(7)$ & C21-Re1-Cl1 & $172.7(4)$ \\
C20-Re1-C21 & $90.9(7)$ & C19-Re1-Cl1 & $89.7(6)$ \\
C19-Re1-N2 & $174.2(6)$ & C20-Re1-Cl1 & $96.3(7)$ \\
C20-Re1-N2 & $97.4(8)$ & N1-Re1-Cl1 & $86.1(4)$ \\
C19-Re1-N1 & $101.1(7)$ & N2-Re1-Cl1 & $92.4(4)$ \\
C20-Re1-N1 & $170.8(8)$ & O5-C19-Re1 & $177(2)$ \\
C21-Re1-N2 & $85.6(5)$ & O6-C20-Re1 & $177(2)$ \\
& & O7-C21-Re1 & $165(2)$
\end{tabular}

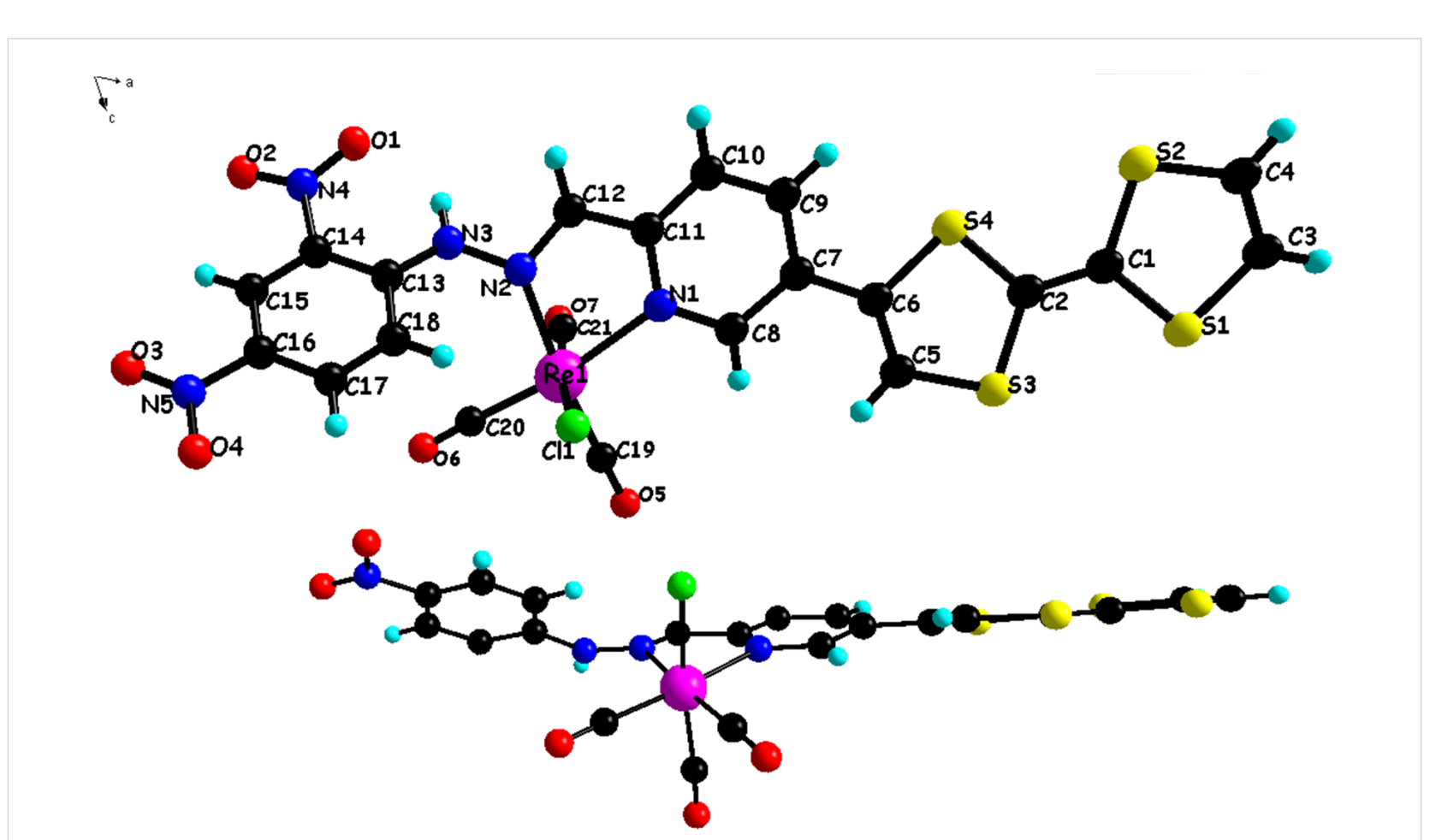

Figure 9: Crystal structure of complex 3 with atom numbering scheme (top) and a side view of the molecule (bottom). Water molecules are omitted for clarity. 


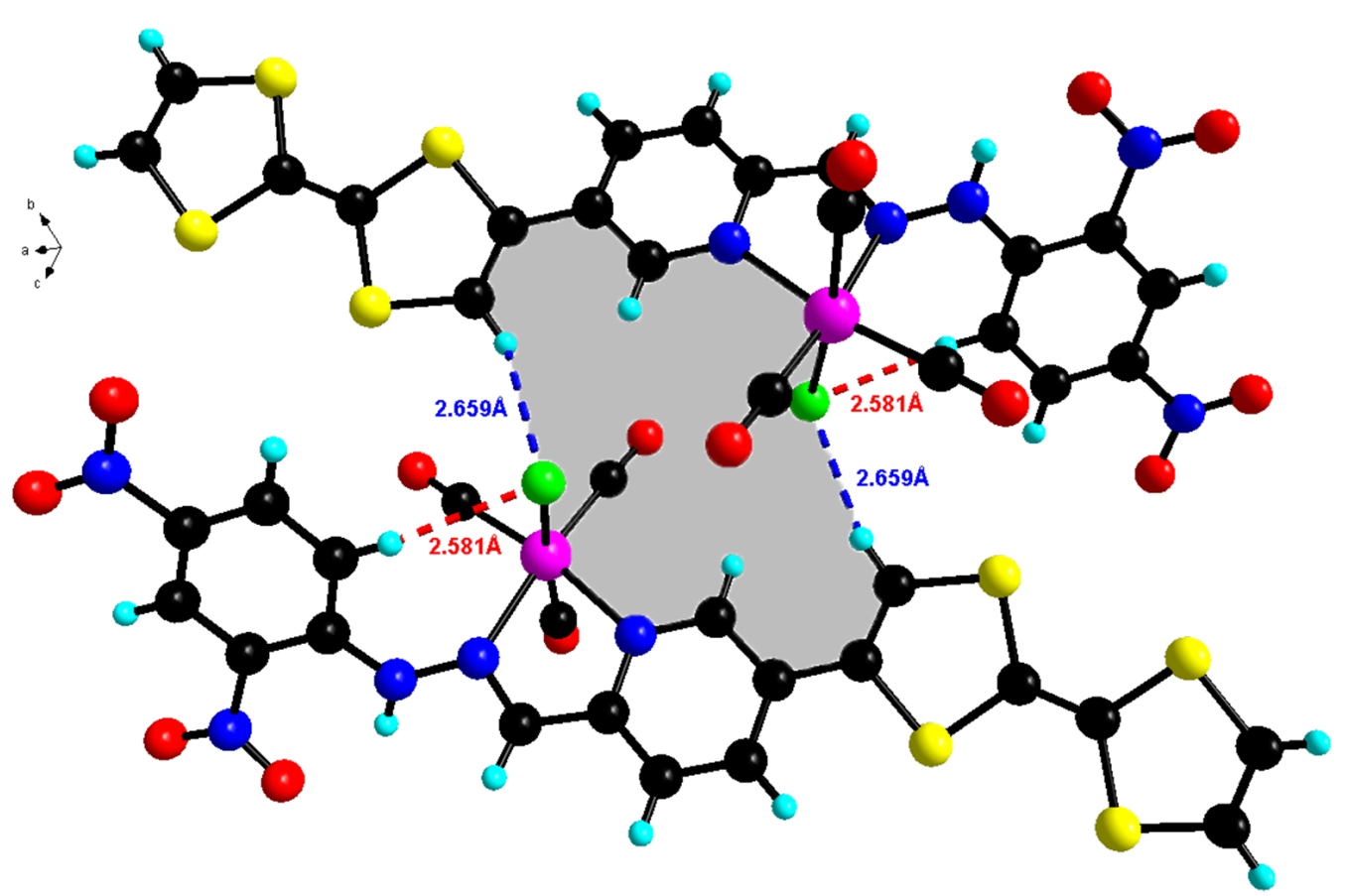

Figure 10: Pattern of intramolecular and intermolecular contacts in 3. Two molecules are linked by pairs of strong TTF-C-H $\cdots \mathrm{Cl}$ hydrogen bonds forming $R_{2}^{2}(16)$ cyclic motifs (in grey filling).

Adjacent dimers interact through hydrogen bonding interaction $\mathrm{C}-\mathrm{H} \cdots \mathrm{O}(\mathrm{H} \cdots \mathrm{O} 2.70(2) \AA)$ formed between the $\mathrm{NO}_{2}$ group and an aromatic $\mathrm{C}-\mathrm{H}$ that results in the establishment of $\mathrm{R}_{2}{ }^{2}(10)$ cyclic motifs (blue filling in Figure 11) and $\mathrm{N}-\mathrm{H} \cdots \mathrm{O}(\mathrm{H} \cdots \mathrm{O}$ 2.32(2) $\AA$ ) hydrogen bonds formed between the second $\mathrm{NO}_{2}$ group and $\mathrm{N}-\mathrm{H}$ that form $\mathrm{R}_{2}{ }^{2}(12)$ cyclic motifs (grey filling in

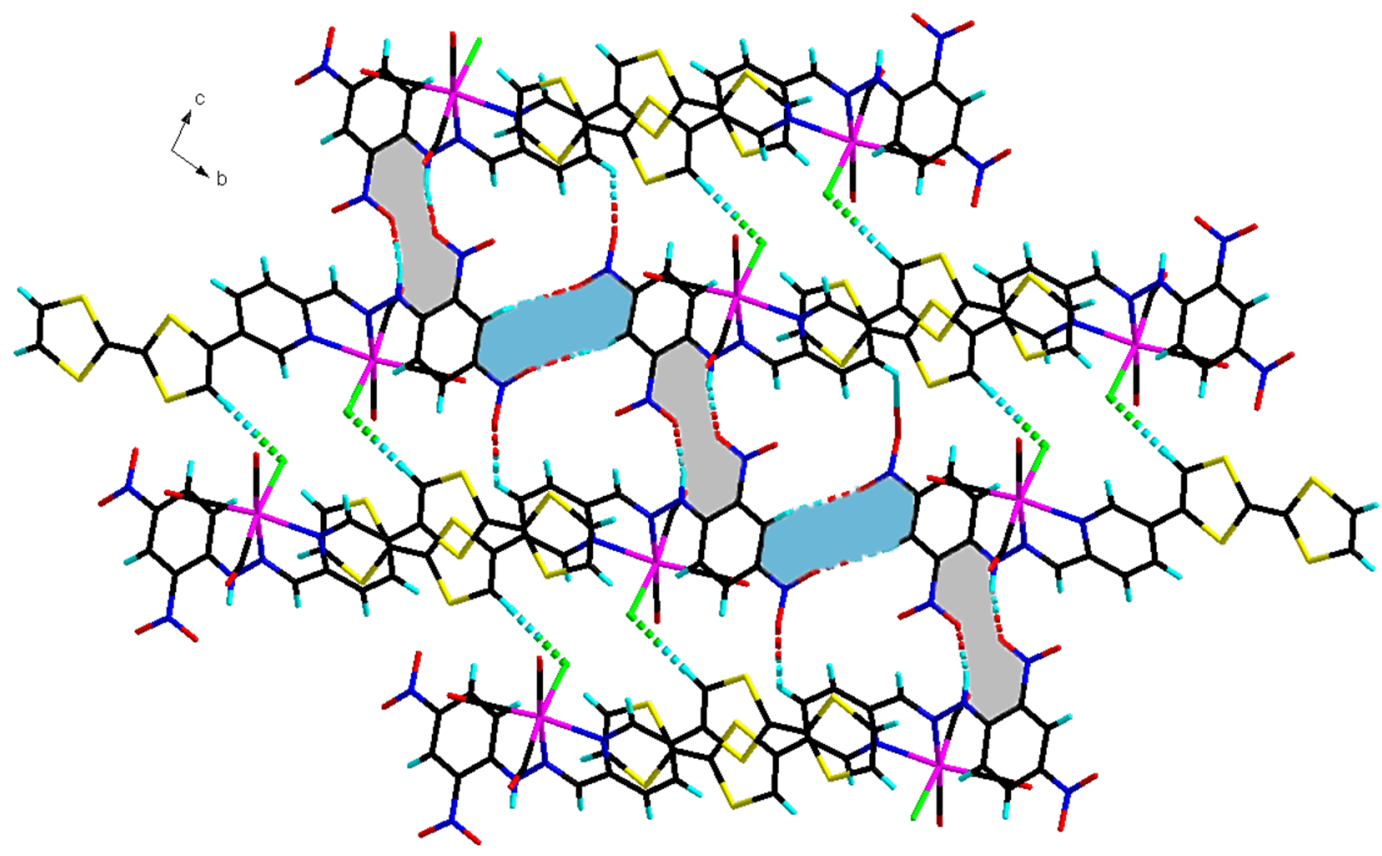

Figure 11: Layered structure of complex 3 viewed along the a-axis. The dimers are linked together through hydrogen bonding that form $R_{2}{ }^{2}(10)$ in blue filling and $R_{2}{ }^{2}(12)$ in grey filling cyclic motifs. 
Figure 11). This hydrogen bonding link therefore the molecules together into layers parallel with the $b c$ crystallographic plane. The dimers of the resulting layers form a stack along $a$-axis through $\mathrm{S} \cdots \mathrm{S}$ contacts $(\mathrm{d}(\mathrm{S} \cdots \mathrm{S})$ being between $3.70(6)$ and 3.90(7) $\AA$ ) resulting into a 3D supramolecular network.

The UV-visible absorption spectrum of the rhenium complex 3 recorded in a mixture of dichloromethane/acetonitrile $(9: 1, \mathrm{v} / \mathrm{v})$ at room temperature $\left(c 1.1 \times 10^{-4} \mathrm{M}\right)$ presents the same features as the free ligand $\mathbf{L} 2$ with a red shift of the different absorption bands (Figure S10 in Supporting Information File 1). The ICT trasnsition suffers a bathochromic shift by about $100 \mathrm{~nm}$ as compared with the free ligand which indicates an increase of the electron acceptor effet of the ligand upon complexation with rhenium which acts as strong Lewis acid.

After complexation, the redox behavior of the TTF moiety is maintained. We note a positive shift of the two oxidation potentials in the case of complex 3 by about $90 \mathrm{mV}$ and $100 \mathrm{mV}$ (Figure S11 in Supporting Information File 1). This increase of the oxidation potential suggests that the rhenium fragment is acting as an electron acceptor by decreasing the electron density on the TTF unit. This behavior is in agreement with the electronic absorption experiments and confirms the strong electronic conjugation in ligand $\mathbf{L 2}$. The electrochemical behavior observed for $\mathbf{L} \mathbf{2}$ and its corresponding rhenium complex $\mathbf{3}$ indicate that this compounds are valuable candidates for the electrochemical formation of air-stable radical cation crystalline salts [16].

\section{Conclusion}

Two multifunctional ligands which associate an electrondonating TTF unit with an electron-accepting dinitrophenyl group as well as a coordinating pyridine azine moiety were successfully synthesized. Ligand $\mathbf{L} 2$ exhibit a strong electronic conjugation between the donor and the acceptor resulting in the occurrence of an intramolecular charge transfer (ICT) band between the two fragments. Single crystals of ligand $\mathbf{L} \mathbf{1}$ have been obtained and its crystal structure indicates the ligand is completely planar with the occurrence of a strong intramolecular as well as intermolecular hydrogen bonding. Inorganic anions titration experiments showed that the two ligands are suitable candidates for the sensing of fluoride anions. Metal cation-coordination experiments afforded the obtaining of a neutral electroactive rhenium(I) complex. The crystal structure of this complex indicates the formation of dimers that are connected through strong hydrogen bonding. The electrochemical behavior of both the ligands and the neutral rhenium(I) complex suggests that crystalline radical cation salts can be readily obtained upon chemical and/or electrochemical oxidation. The complexation abililty of the two novel electroactive ligands toward transition metal cations such as $\mathrm{Cu}(\mathrm{II}), \mathrm{Fe}(\mathrm{II})$, $\mathrm{Co}(\mathrm{II})$, etc is in progress.

\section{Experimental General information}

NMR spectra were recorded on a Bruker Avance DRX 300 spectrometer operating at $300 \mathrm{MHz}$ for ${ }^{1} \mathrm{H}$ NMR and $75 \mathrm{MHz}$ for ${ }^{13} \mathrm{C}$ NMR. Chemical shifts are expressed in parts per million (ppm) downfield from external TMS. UV-visible spectra were recorded at room temperature in quartz cuvettes using Perkin Elmer spectrophotometer. Mass spectra were collected with Bruker Biflex-III TM. IR spectra were recorded on a Bruker vertex 70. Elemental (C, H and $\mathrm{N}$ ) analyses were performed on a Thermo-Scientific Flash 2000 Organic Elemental Analyzer. Cyclic voltammetry $(\mathrm{CV})$ experiments were performed in a three-electrode cell equipped with a platinum millielectrode as the working electrode, a platinum wire as a counter electrode and a silver wire $\mathrm{Ag} / \mathrm{Ag}^{+}$used as a reference electrode. The electrolytic media involved a $0.1 \mathrm{~mol} / \mathrm{L}$ solution of $\left(n-\mathrm{Bu}_{4} \mathrm{~N}\right) \mathrm{PF}_{6}$ in dichloromethane/acetonitrile $(9: 1, \mathrm{v} / \mathrm{v})$. Melting points were measured with a Melting Point Apparatus SMP3.

X-ray single-crystal diffraction data for complex 3 were collected at $180 \mathrm{~K}$ on an Agilent SuperNova diffractometer equipped with Atlas CCD detector and mirror monochromated micro-focus $\mathrm{Cu} \mathrm{K}_{\alpha}$ radiation $(\lambda=1.54184 \AA$ ) . For ligand L1, crystal data were collected at $293 \mathrm{~K}$ on a Bruker KappaCCD diffractometer, equipped with a graphite monochromator utilizing MoK $\alpha$ radiation $(\lambda=0.71073 \AA)$. The two structures were solved by direct methods, expanded and refined on $\mathrm{F}^{2}$ by full matrix least-squares techniques using SHELX97 programs (G.M. Sheldrick, 1998). All non-H atoms were refined anisotropically and the $\mathrm{H}$ atoms were included in the calculation without refinement. Multiscan empirical absorption was corrected using the SADABS program (Bruker AXS area detector scaling and absorption correction, v2008/1, Sheldrick, G.M., (2008)) for ligand L1 and using the CrysAlisPro program (CrysAlisPro, Agilent Technologies, V1.171.37.35g, 2014) for complex 3. For ligand L1, the structure refinement showed disordered electron density which could not be reliably modeled and the program PLATON/SQUEEZE were used to remove the scattering contribution corresponding to dimethyl sulfoxide solvent from the intensity data. The assumed solvent composition (3 DMSO per asymmetric unit) was used in the calculation of the empirical formula, formula weight, density, linear absorption coefficient and $\mathrm{F}(000)$. For complex 3, the largest difference peak and hole of $2.29 \mathrm{e} \AA^{-3}$ observed is relatively high and it can be attributed to bad absorption correction. As the Gaussian absorption method does not improve the refinement, we have chosen the empirical absorption correction. This residual electronic density is located around the Re metal ion. 
6-([2,2'-Bi(1,3-dithiolylidene)]-4-yl)picolinaldehyde (1): This compound was prepared as previously described [38]. Stannylated tetrathiafulvalene $(0.50 \mathrm{~g}, 1.36 \mathrm{mmol})$ and 6-bromo-2pyridinecarboxaldehyde $(0.34 \mathrm{~g}, 1.36 \mathrm{mmol})$ were dissolved in toluene $(20 \mathrm{~mL})$ and $\left[\mathrm{Pd}\left(\mathrm{PPh}_{3}\right)_{4}\right](0.156 \mathrm{~g}, 0.135 \mathrm{mmol})$ was added. The reaction mixture was heated for 48 hours at $110^{\circ} \mathrm{C}$. After evaporation of the solvent under reduced pressure, the obtained residue was then passed over a silica gel column chromatography using a gradient of eluent (pentane/dichloromethane, $3: 1, \mathrm{v} / \mathrm{v})$. After solvent evaporation, a solid was obtained in $60 \%$ yield, $(0.250 \mathrm{~g}, 0.809 \mathrm{mmol})$; mp $152{ }^{\circ} \mathrm{C}$; ${ }^{1} \mathrm{H}$ NMR $\left(300 \mathrm{MHz}, \mathrm{DMSO}-d_{6}\right) \delta 9.95(\mathrm{~s}, 1 \mathrm{H}), 8.19(\mathrm{~d}$, $J=7.21 \mathrm{~Hz}, 1 \mathrm{H}), 8.10(\mathrm{t}, J=7.89 \mathrm{~Hz}, 1 \mathrm{H}), 7.88(\mathrm{~s}, 1 \mathrm{H}), 7.85$ $(\mathrm{d}, J=7.50 \mathrm{~Hz}, 1 \mathrm{H}), 6.78(\mathrm{~s}, 2 \mathrm{H}) \mathrm{ppm} ;{ }^{13} \mathrm{C} \mathrm{NMR}(75 \mathrm{MHz}$, DMSO- $\left.d_{6}\right) \delta 193.3,152.0,150.9,138.8,136.7,124.2,122.3$, $121.2,120.7,120.5,112.3,107.5 \mathrm{ppm}$; anal. calcd for $\mathrm{C}_{12} \mathrm{H}_{7} \mathrm{NOS}_{4}$ : C, 46.58; H, 2.28; N, 4.53; found: C, 46.16; H, 2.22; N, 4.43; MALDI-TOF MS calcd: $m / z=309.5$. found: $m / z=308.9[\mathrm{M}]^{+}$; HRMS (M): calcd for $\mathrm{C}_{12} \mathrm{H}_{7} \mathrm{NOS}_{4}$ : 308.9410 ; found: 308.9413 .

5-([2,2'-Bi(1,3-dithiolylidene)]-4-yl)picolinaldehyde (2): This compound was prepared by following the same procedure as for compound 1. Yield (65\%); mp $191{ }^{\circ} \mathrm{C} ;{ }^{1} \mathrm{H}$ NMR $(300 \mathrm{MHz}$, DMSO-d $\left.d_{6}\right) \delta 9.98(\mathrm{~s}, 1 \mathrm{H}), 8.97(\mathrm{~d}, J=1.65 \mathrm{~Hz}, 1 \mathrm{H}), 8.07$ (dd, $J=6.42 \mathrm{~Hz}, J=2.08 \mathrm{~Hz}, 1 \mathrm{H}), 7.96(\mathrm{~d}, J=8.30 \mathrm{~Hz}, 1 \mathrm{H}), 7.78$ $(\mathrm{s}, 1 \mathrm{H}), 6.81(\mathrm{~s}, 2 \mathrm{H}) \mathrm{ppm} ;{ }^{13} \mathrm{C} \mathrm{NMR}\left(75 \mathrm{MHz}, \mathrm{DMSO}-d_{6}\right) \delta$ 193.2, 151.5, 147.4, 134.7, 131.8, 130.8, 122.6, 122.5, 120.7, 120.6, 114.2, 105.7 ppm; anal. calcd for $\mathrm{C}_{12} \mathrm{H}_{7} \mathrm{NOS}_{4}$ : C, 46.58; $\mathrm{H}, 2.28 ; \mathrm{N}, 4.53$; found: $\mathrm{C}, 46.54 ; \mathrm{H}, 2.20 ; \mathrm{N}, 4.51$; MALDI-TOF MS calcd: $m / z=309.5$. found: $m / z=308.9[\mathrm{M}]^{+}$. HRMS (M): calcd for $\mathrm{C}_{12} \mathrm{H}_{7} \mathrm{NOS}_{4}$ : 308.9410 ; found: 308.9404 .

2-([2,2'-Bi(1,3-dithiolylidene)]-4-yl)-6-((2,4-dinitrophenyl)hydrazono)methyl)pyridine (L1): 2,4-Dinitrophenylhydrazine $(0.150 \mathrm{~g}, 0.757 \mathrm{mmol})$ and 6-([2,2'-bi(1,3-dithiolylidene)]-4yl)picolinaldehyde $(1,0.234 \mathrm{~g}, 0.757 \mathrm{mmol})$ were dissolved in ethanol $(20 \mathrm{~mL})$ and three drops of acetic acid were added. The resulting solution was refluxed overnight. After cooling to room temperature, a dark precipitate was formed which was filtered and washed with ethanol then dried under vacuum to afford a dark powder of ligand L1, 75\% (0.277 g, $0.567 \mathrm{mmol})$; mp $264{ }^{\circ} \mathrm{C} ;{ }^{1} \mathrm{H}$ NMR (300 MHZ, DMSO-d 6 ) $\delta 11.87$ (s, $1 \mathrm{H}$, -NH), $8.90(\mathrm{~d}, J=2.60 \mathrm{~Hz}, 1 \mathrm{H}), 8.78(\mathrm{~s}, 1 \mathrm{H}), 8.43$ (dd, $J=6.48 \mathrm{~Hz}, J=2.70 \mathrm{~Hz}, 1 \mathrm{H}), 8.19(\mathrm{~d}, J=9.40 \mathrm{~Hz}, 1 \mathrm{H}), 7.98$ $(\mathrm{m}, 3 \mathrm{H}), 7.78(\mathrm{~s}, 1 \mathrm{H}), 6.78(\mathrm{~s}, 2 \mathrm{H}) \mathrm{ppm} ;{ }^{13} \mathrm{C} \mathrm{NMR}(75 \mathrm{MHz}$, DMSO- $\left.d_{6}\right) \delta 160.8,154.6,147.3,144.7,141.6,140.6,138.4$, $134.2,134.1,131.0,130.2,129.2,123.3,120.5,117.5$ ppm; selected IR bands $\left(\mathrm{cm}^{-1}\right): 1614,1499,1333$; anal. calcd for $\mathrm{C}_{18} \mathrm{H}_{11} \mathrm{~N}_{5} \mathrm{O}_{4} \mathrm{~S}_{4}$ : C, 44.15; H, 2.26; N, 14.30, found: C, 43.54; H, 2.22; N, 13.66; MALDI-TOF MS calcd: $m / z=489.6$. found: $m / z=489.1[\mathrm{M}]^{+}$; HRMS (M): calcd for $\mathrm{C}_{18} \mathrm{H}_{11} \mathrm{~N}_{5} \mathrm{O}_{4} \mathrm{~S}_{4}$ : 488.9694; found: 488.9687 .

5-([2,2'-bi(1,3-dithiolylidene)]-4-yl)-2-((2,4-dinitrophenyl)hydrazono)methyl)pyridine (L2): This ligand was prepared by following the same procedure used for L1. Yield: $63 \%$; mp $257{ }^{\circ} \mathrm{C} ;{ }^{1} \mathrm{H}$ NMR $\left(300 \mathrm{MHz}, \mathrm{DMSO}-d_{6}\right) \delta 11.88(\mathrm{~s}, 1 \mathrm{H}$, -NH), $8.88(\mathrm{~d}, J=2.64 \mathrm{~Hz}, 1 \mathrm{H}), 8.75(\mathrm{~d}, J=2.34 \mathrm{~Hz}, 1 \mathrm{H}), 8.72$ $(\mathrm{s}, 1 \mathrm{H}), 8.41(\mathrm{dd}, J=6.96 \mathrm{~Hz}, J=2.63 \mathrm{~Hz}, 1 \mathrm{H}), 8.17$ (d, $J=9.63 \mathrm{~Hz}, 1 \mathrm{H}), 8.11(\mathrm{~d}, J=8.13 \mathrm{~Hz}, 1 \mathrm{H}), 7.96(\mathrm{dd}$, $J=5.99 \mathrm{~Hz}, J=2.40 \mathrm{~Hz}, 1 \mathrm{H}), 7.58(\mathrm{~s}, 1 \mathrm{H}), 6.79$ (s, 2H) ppm; ${ }^{13} \mathrm{C}$ NMR $\left(75 \mathrm{MHz}, \mathrm{DMSO}-d_{6}\right) \delta 152.6,148.6,147,144.7$, 138.3, 134.2, 131.3, 130.8, 130.3, 128.6, 123.3, 121.1, 120.7, 117.7, 113.6, 106.3 ppm; selected IR bands $\left(\mathrm{cm}^{-1}\right)$ : 1612, 1508, 1325; anal. calcd for $\mathrm{C}_{18} \mathrm{H}_{11} \mathrm{~N}_{5} \mathrm{O}_{4} \mathrm{~S}_{4}$ : C, 44.15; H, 2.26; N, 14.30; S, 26.19, found: C, 43.69; H, 2.16; N, 13.98; S, 26.01; MALDI-TOF MS calcd: $m / z=489.6$. found: $m / z=489.0[\mathrm{M}]^{+}$; HRMS (M): calcd for $\mathrm{C}_{18} \mathrm{H}_{11} \mathrm{~N}_{5} \mathrm{O}_{4} \mathrm{~S}_{4}$ : 488.9694; found: 488.9703.

Rhenium(I) complex [ $\left.\operatorname{ReL2}(\mathrm{CO})_{3} \mathrm{Cl}\right]$ 3: To a solution of ligand $\mathbf{L 2}(0.025 \mathrm{~g}, 0.051 \mathrm{mmol})$ in a mixture of toluene and dichloromethane $(3: 1, \mathrm{v} / \mathrm{v})$ solution was added $\left[\mathrm{Re}(\mathrm{CO})_{5} \mathrm{Cl}\right]$ $(0.027 \mathrm{~g}, 0.076 \mathrm{mmol})$. The mixture was refluxed for 6 hours under nitrogen atmosphere. After cooling the resulting mixture to room temperature, the solvent was removed by a rotary evaporator. The brown residue was extracted with dichloromethane and recrystallized from acetone/hexane solvent mixture to yield complex 3 as black crystals with $81 \%$ yield $(0.033 \mathrm{~g}$, $0.041 \mathrm{mmol}) ; \mathrm{mp}>360{ }^{\circ} \mathrm{C} ;{ }^{1} \mathrm{H}$ NMR $\left(300 \mathrm{MHz}, \mathrm{DMSO}-d_{6}\right) \delta$ $12.35(\mathrm{~s}, 1 \mathrm{H}), 9.36(\mathrm{~m}, 1 \mathrm{H}), 9.02(\mathrm{~s}, 1 \mathrm{H}), 8.91(\mathrm{~s}, 1 \mathrm{H}), 8.32(\mathrm{~m}$, $3 \mathrm{H}), 8.0(\mathrm{~s}, 1 \mathrm{H}), 7.84(\mathrm{~m}, 1 \mathrm{H}), 6.83(\mathrm{~s}, 2 \mathrm{H}) \mathrm{ppm} ;{ }^{13} \mathrm{C} \mathrm{NMR}$ $\left(75 \mathrm{MHz}, \mathrm{DMSO}-d_{6}\right) \delta 197.6,196.8,193.0,152.5,148.5$, $147.6,144.7,138.2,136.4,134.1,131.2,130.8,130.2,129.2$, $128.5,123.3,121.0,120.7,117.7,113.6,106.3 \mathrm{ppm}$; selected IR bands $\left(\mathrm{cm}^{-1}\right): 2018,1868,1614,1497,1333$; MALDI-TOF MS calcd: $m / z=795.3$. found: $m / z=795.2[\mathrm{M}]^{+}$; HRMS (M): calcd for $\mathrm{C}_{21} \mathrm{H}_{11} \mathrm{O}_{7} \mathrm{~N}_{5} \mathrm{~S}_{4} \mathrm{ReCl}$ : 794.8787; found: 794.8781 .

\section{Supporting Information}

\section{Supporting Information File 1}

Additional analytical data.

[http://www.beilstein-journals.org/bjoc/content/

supplementary/1860-5397-11-149-S1.pdf]

\section{Acknowledgements}

The Johnson-Matthey company is acknowledged for the generous providing of palladium salt. 


\section{References}

1. Bendikov, M.; Wudl, F.; Perepichka, D. F. Chem. Rev. 2004, 104, 4891-4946. doi:10.1021/cr030666m

2. Wudl, F.; Wobschall, D.; Hufnagem, E. J. J. Am. Chem. Soc. 1972, 94, 670-672. doi:10.1021/ja00757a079

3. Ferraris, J.; Cowan, D. O.; Walatka, V.; Perlstein, J. H. J. Am. Chem. Soc. 1973, 95, 948-949. doi:10.1021/ja00784a066

4. Molecular conductors. Chem. Rev. 2004, 104, 4887-5782.

5. Martín, N. Chem. Commun. 2013, 49, 7025-7027. doi:10.1039/c3cc00240c

6. Williams, J. M.; Ferraro, J. R.; Thorn, R. J.; Carlson, K. D.; Geiser, U. Wang, H. H.; Kini, A. M.; Whangbo, M.-H. Organic Superconductors (Including fullerenes), Synthesis, Structure, properties and Theory; Prentice Hall: Upper Saddle River, NJ, U.S.A., 1992.

7. Bryce, M. R.; Murphy, L. C. Nature 1984, 309, 119-126. doi:10.1038/309119a0

8. McCall, K. L.; Morandeira, A.; Durrant, J.; Yellowlees, L. J.; Robertson, N. Dalton Trans. 2010, 39, 4138-4145. doi:10.1039/b924660f

9. Wenger, S.; Bouit, P.-A.; Chen, Q. L.; Teuscher, J.; Di Censo, D.; Humphry-Baker, R.; Moser, J.-E.; Delgado, J. L.; Martín, N.; Zakeeruddin, S. M.; Grätzel, M. J. Am. Chem. Soc. 2010, 132, 5164-5169. doi:10.1021/ja909291h

10. de Lucas, A. I.; Martín, N.; Sánchez, L.; Seoane, C.; Andreu, R.; Garín, J.; Orduna, J.; Alcalá, R.; Villacampa, B. Tetrahedron 1998, 54, 4655-4662. doi:10.1016/S0040-4020(98)00182-3

11. González, M.; Segura, J. L.; Seoane, C.; Martín, N.; Garín, J.; Orduna, Jesús; Alcalá, R.; Villacampa, B.; Hernández, V.; López Navarrete, J. T. J. Org. Chem. 2001, 66, 8872-8882. doi:10.1021/jo010717k

12. Ouahab, L. Chem. Mater. 1997, 9, 1909-1926. doi:10.1021/cm9701217

13. Coronado, E.; Galán-Marcós, J. R.; Gómez-García, C. J.; Laukhin, V. Nature 2000, 408, 447-449. doi:10.1038/35044035

14. Ouahab, L.; Enoki, T. Eur. J. Inorg. Chem. 2004, 933-941. doi:10.1002/ejic.200300869

15. Coronado, E.; Day, P. Chem. Rev. 2004, 104, 5419-5448. doi:10.1021/cr030641n

16. Setifi, F.; Ouahab, L.; Golhen, S.; Yoshida, Y.; Saito, G. Inorg. Chem. 2003, 42, 1791-1793. doi:10.1021/ic026211h

17. Nihei, M.; Takahashi, N.; Nishikawa, H.; Oshio, H. Dalton Trans. 2011, 40, 2154-2156. doi:10.1039/CODT01092H

18. Canevet, D.; Sallé, M.; Zhang, G.; Zhang, D.; Zhu, D. Chem. Commun. 2009, 2245-2269. doi:10.1039/b818607n

19. Nielsen, M. B.; Lomholt, C.; Becher, J. Chem. Soc. Rev. 2000, 29, 153-164. doi:10.1039/a803992e

20. Segura, J. L.; Martín, N. Angew. Chem., Int. Ed. 2001, 40, 1372-1409. doi:10.1002/1521-3773(20010417)40:8<1372::AID-ANIE1372>3.0.CO; 2-I

21. Yamada, J.; Sugimoto, T. TTF Chemistry: Fundamentals \& Applications of Tetrathiafulvalene; Kodansha and Springer: Tokyo, Japan and Berlin, Germany, 2004.

22. Hardouin-Lerouge, M.; Hudhomme, P.; Sallé, M. Chem. Soc. Rev. 2011, 40, 30-43. doi:10.1039/B915145C

23. Lehn, J. M. Chapter 3. Supramolecular Chemistry: Concepts and Perspectives; Wiley-VCH: New York, NY, U.S.A., 1995.

24. Bianchi, E.; Bowman-James, K.; García-España, E. Supramolecular Chemistry of Anions; Wiley-VCH: New York, NY, U.S.A., 1997

25. Schmidtchen, F. P.; Berger, M. Chem. Rev. 1997, 97, 1609-1646. doi: $10.1021 / \mathrm{cr} 9603845$
26. Beer, P. D. Acc. Chem. Res. 1998, 31, 71-80. doi:10.1021/ar9601555

27. Bowman-James, K. Acc. Chem. Res. 2005, 38, 671-678. doi:10.1021/ar040071t

28. Sessler, J. L.; Gale, P. A.; Cho, W. S. Anion Receptor Chemistry; Royal Society of Chemistry: Cambridge, United Kingdom, 2006.

29. Caltagirone, C.; Gale, P. A. Chem. Soc. Rev. 2009, 38, 520-563. doi:10.1039/B806422A

30. Gale, P. A.; García-Garrido, S. E.; Garric, J. Chem. Soc. Rev. 2008, 37, 151-190. doi:10.1039/B715825D

31. Suksai, C.; Tuntulani, T. Chem. Soc. Rev. 2003, 32, 192-202. doi:10.1039/b209598j

32. Kirk, K. L. Biochemistry of the Halogens and Inorganic Halides, Biochemistry of the Elements, Vol. 9A+B; Springer: New York, NY, U.S.A., 1991; pp 58 ff. doi:10.1007/978-1-4684-5817-6

33. Hudnall, T. W.; Chiu, C.-W.; Gabbaï, F. P. Acc. Chem. Res. 2009, 42, 388-397. doi:10.1021/ar8001816

34. Lee, C.-H.; Miyaji, H.; Yoon, D.-W.; Sessler, J. L. Chem. Commun. 2008, 24-34. doi:10.1039/B713183F

35. Belhadj, E.; El-Ghayoury, A.; Cauchy, T.; Allain, M.; Mazari, M.; Sallé, M. Eur. J. Inorg. Chem. 2014, 3912-3919. doi:10.1002/ejic.201402073 And references therein.

36. Xiong, J.; Cui, L.; Liu, W.; Beves, J. E.; Li, Y.-Y.; Zuo, J.-L. Tetrahedron Lett. 2013, 54, 1998-2000. doi:10.1016/j.tetlet.2013.02.005 And references therein.

37. Shi, Z.; Han, Q.-H.; Li, X.-Y.; Shao, M.-Y.; Zhu, Q.-Y.; Dai, J. Dalton Trans. 2011, 40, 7340-7347. doi:10.1039/c1dt10353a

38. Chahma, M.; Wang, X. S.; van der Est, A.; Pilkington, M. J. Org. Chem. 2006, 71, 2750-2755. doi:10.1021/jo0525938

39. Yu, M.; Fan, Z.; Jing, Z.-L.; Chen, X.; Diao, C.-H.; Deng, Q.-L. Acta Crystallogr. 2005, E61, 03342-03343. doi:10.1107/S160053680502934X

40. Gaussian03, Revision B.04; Gaussian, Inc.: Pittsburgh, PA, U.S.A., 2003.

41. Zhou, L.; Zhang, X.; Wu, S. Chem. Lett. 2004, 33, 850-851. doi:10.1246/cl.2004.850

42. Chawla, H. M.; Sahu, S. N.; Shrivastava, R.; Kumar, S. Tetrahedron Lett. 2012, 53, 2244-2247. doi:10.1016/j.tetlet.2012.02.083

43. Sun, Y.; Liu, Y.; Guo, W. Sens. Actuators, B 2009, 143, 171-176. doi:10.1016/j.snb.2009.09.038

44. Li, J.; Lin, H.; Cai, Z.; Lin, H. Spectrochim. Acta, Part A 2009, 72 1062-1065. doi:10.1016/j.saa.2008.12.045

45. Upadhyay, K. K.; Mishra, R. K.; Kumar, V.; Chowdhury, P. K. R. Talanta 2010, 82, 312-319. doi:10.1016/j.talanta.2010.04.041

46. Amendola, V.; Esteban-Gómez, D.; Fabbrizzi, L.; Licchelli, M. Acc. Chem. Res. 2006, 39, 343-353. doi:10.1021/ar050195।

47. Jia, H.-P.; Forgie, J. C.; Liu, S.-X.; Sanguinet, L.; Levillain, E.; Le Derf, F.; Sallé, M.; Neels, A.; Skabara, P. J.; Decurtins, S. Tetrahedron 2012, 68, 1590-1594. doi:10.1016/j.tet.2011.11.087

48. Singh, A.; Chandra, M.; Sahay, A. N.; Pandey, D. S.; Pandey, K. K.; Mobin, S. M.; Carmen Puerta, M.; Valerga, P. J. Organomet. Chem. 2004, 689, 1821-1834. doi:10.1016/j.jorganchem.2004.02.037

49. Sarjit Singh, K.; Mozharivskyj, Y. A.; Thöne, C.; Rao Kollipara, M. J. Organomet. Chem. 2005, 690, 3720-3729. doi:10.1016/j.jorganchem.2005.05.001

50. Liu, W.; Heinze, K. Dalton Trans. 2010, 39, 9554-9564. doi:10.1039/c0dt00393j 
51. El-Ghayoury, A.; Leliège, A.; Allain, M.; Batail, P. Tetrahedron Lett. 2013, 54, 4015-4018. doi:10.1016/j.tetlet.2013.05.060

\section{License and Terms}

This is an Open Access article under the terms of the Creative Commons Attribution License

(http://creativecommons.org/licenses/by/2.0), which permits unrestricted use, distribution, and reproduction in any medium, provided the original work is properly cited.

The license is subject to the Beilstein Journal of Organic Chemistry terms and conditions:

(http://www.beilstein-journals.org/bjoc)

The definitive version of this article is the electronic one which can be found at:

doi:10.3762/bjoc. 11.149 